\title{
Impact of gully erosion on carbon sequestration in blanket peatlands
}

\author{
Martin Evans ${ }^{1, *}$, John Lindsay ${ }^{2}$ \\ ${ }^{1}$ Upland Environments Research Unit, School of Environment and Development, University of Manchester, \\ Manchester M19 3PL, UK \\ ${ }^{2}$ Department of Geography, University of Guelph, 50 Stone Road East, Guelph, Ontario N1G 2W1, Canada
}

\begin{abstract}
Over $50 \%$ of UK soil carbon is stored in peatland systems and $75 \%$ of these peatlands are upland blanket bog. The upland blanket bogs of the UK have suffered severe erosion over the last millennium so that they are widely dissected by gully systems. Gully erosion entails primary removal of particulate carbon from the peatland system but also has secondary effects in that it enhances drainage and lowers water tables, potentially enhancing decomposition of surface peats. This paper exploits recent high resolution mapping of the gully erosion on the Bleaklow Plateau in the southern Pennines and existing data on peat growth rates in the area to assess the impact of gully erosion on peatland carbon balance and the relative importance of primary and secondary impacts of gullying on carbon sequestration. The results indicate that gully erosion during the last millennium has shifted the Bleaklow Plateau from being a net sink of carbon $\left(-20.3 \mathrm{~g} \mathrm{C} \mathrm{m}^{-2} \mathrm{yr}^{-1}\right)$ to a net source $\left(29.4 \mathrm{~g} \mathrm{C} \mathrm{m}^{-2}\right.$ $\left.\mathrm{yr}^{-1}\right)$. The relative importance of gullying impacts can be expressed as follows: particulate organic carbon (POC) flux > change in gully net ecosystem exchange $\gg$ loss of gully margin carbon sequestration. The implication of these findings is that the magnitude of the potentially reversible impacts of gully erosion (reduced carbon fixation due to vegetation loss and ongoing erosional loss of POC) far exceed the effects associated with irreversible morphological change (enhanced peat decomposition in gully margin locations).
\end{abstract}

KEY WORDS: Blanket peat · Gully erosion $\cdot$ Carbon balance $\cdot$ Carbon sequestration Resale or republication not permitted without written consent of the publisher

\section{INTRODUCTION}

Actively growing peatlands fix carbon, and because of the cumulic nature of peatland soils this carbon enters long-term storage within stable peat systems. Worrall et al. (2003) suggest that typical rates of carbon fixation by UK blanket peatlands are in the range of 40 to $70 \mathrm{~g} \mathrm{C} \mathrm{m}^{-2} \mathrm{yr}^{-1}$. Blanket peat formation in the UK began as early as 9200 yr BP (Charman 1992), with widespread development of upland peatlands through the mid-Holocene (Tallis 1991). In the UK, soil carbon is the largest terrestrial carbon store with $>10$ gigatonnes (Gt) of carbon (Milne \& Brown 1997). As a consequence of the long-term accumulation of carbon in upland peatland systems, $>50 \%$ of UK soil carbon storage occurs in peatlands and $>1.5 \mathrm{Gt}$ of carbon are stored in upland blanket peats (Milne \& Brown 1997). These peatlands have been significantly degraded by widespread gully erosion in the last millennium (Tallis 1998; Fig. 1). Across the UK and Ireland, between 5 and $33 \%$ of blanket peatlands are affected by gully erosion (Evans \& Warburton 2007)

The physical and biogeochemical disruption of the peatland system caused as peatlands are dissected by gully erosion has the potential to significantly impact the functioning of the bog ecosystem, and hence modify the ability of the bog to sequester carbon.

The impact of gully erosion on rates of peatland carbon storage can be subdivided into direct carbon losses through the physical erosion of the peat mass, and indirect effects related to modifications to peatland function in response to gullying. For example, peat erosion causes reductions in the local water table due to local drainage of the peatland and there is good evidence that reductions in the bog water table are likely to enhance peat decomposition, leading to increased 


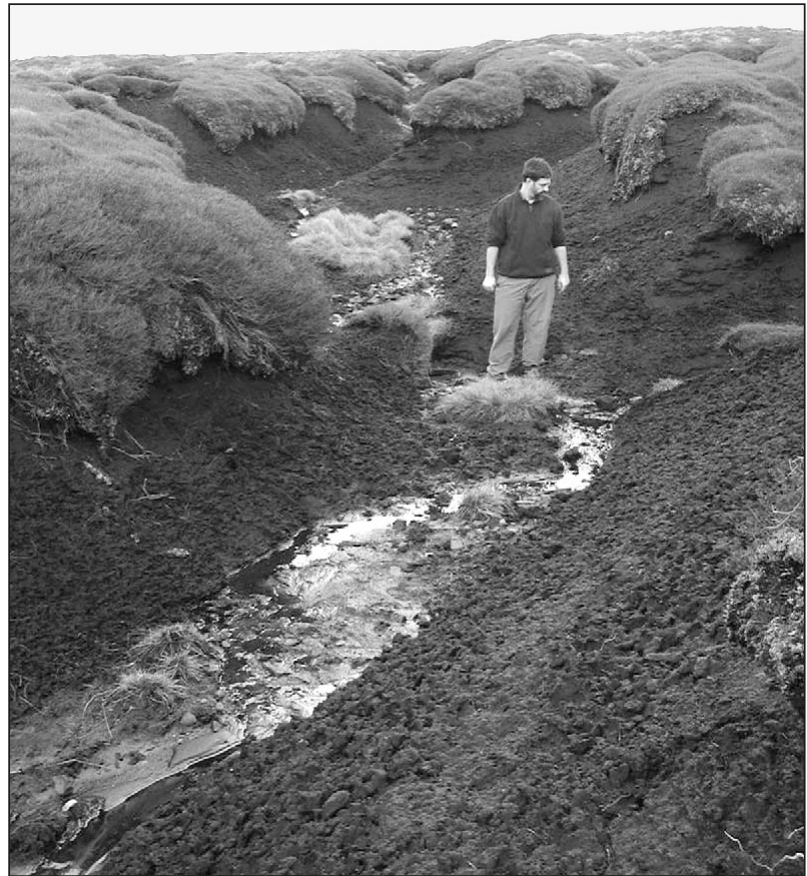

Fig. 1. Severe gully erosion of blanket peat in the southern Pennines

rates of $\mathrm{CO}_{2}$ flux to the atmosphere and increased losses of dissolved organic carbon (DOC) (Silvola et al. 1996, Waddington et al. 1998, Blodau et al. 2004, Strack et al. 2008).

The climate envelope modelling reported in Clark et al. (2010, this Special) indicates that UK peatlands will be subject to considerable climate stress over the next century. Existing peatland erosion has developed in response to multiple stresses on the peatland vegetation including desiccation in the medieval warm period (1150-1300 AD) (Tallis 1995, 1998). There is therefore a risk that severe moisture stress on the peatland surface under changing climate conditions will trigger widespread peat erosion and reactivation of eroded but currently revegetated systems. The risk that peat erosion may become more widespread under conditions of predicted climate change means that there is an important need to understand the impacts of erosion on peatland carbon balance and, consequently, potential feedbacks to atmospheric carbon levels.

The present study aimed to quantify for the first time the impact of gully erosion on peatland carbon sequestration at the landcscape scale, to analyse the relative contribution of various causes of carbon loss and to assess the implications of these data to attempts to restore eroded upland peatlands. We used available evidence to assess the impact of the gully erosion of the last millennium on rates of carbon sequestration in the southern Pennines, an area of severely eroded blanket peats towards the southernmost extent of the Northern Hemisphere distribution of blanket bog (Lindsay et al. 1988). The approach taken was to combine existing data on peat growth rates (interpreted as carbon sequestration) with new approaches to mapping gully erosion in peatlands in order to estimate the impact of gully erosion on the carbon balance of the system.

\section{STUDY SITE}

The present study focussed on an area of severely degraded blanket peatland in the southern Pennines of the UK. The Bleaklow Plateau (Fig. 2) ranges in elevation from ca. 500 to $632 \mathrm{~m}$ in elevation and is an area of blanket peatland with typically $2 \mathrm{~m}$ of peat overlying periglacial head deposits and gritstone bedrock. The vegetation is characterised by extensive cottongrass and heather cover. The principal vegetation associations are Calluna vulgaris-Eriophorum vaginatum (blanket mire) and Eriophorum vaginatum (raised and blanket mire) - UK national vegetation classifications M19 and M20, respectively; (Rodwell 1991). In eroded areas, Vaccinium myrtillus is also widespread, particularly on dry gully edges. The plateau is amongst the southernmost areas of extensive deep peat in the UK and has an annual precipitation level of $1400 \mathrm{~mm}$. Erosion is extensive across the plateau; $34 \%$ of the area is occupied by gullies (Evans \& Lindsay 2010). A range of factors have contributed to the extensive erosion of

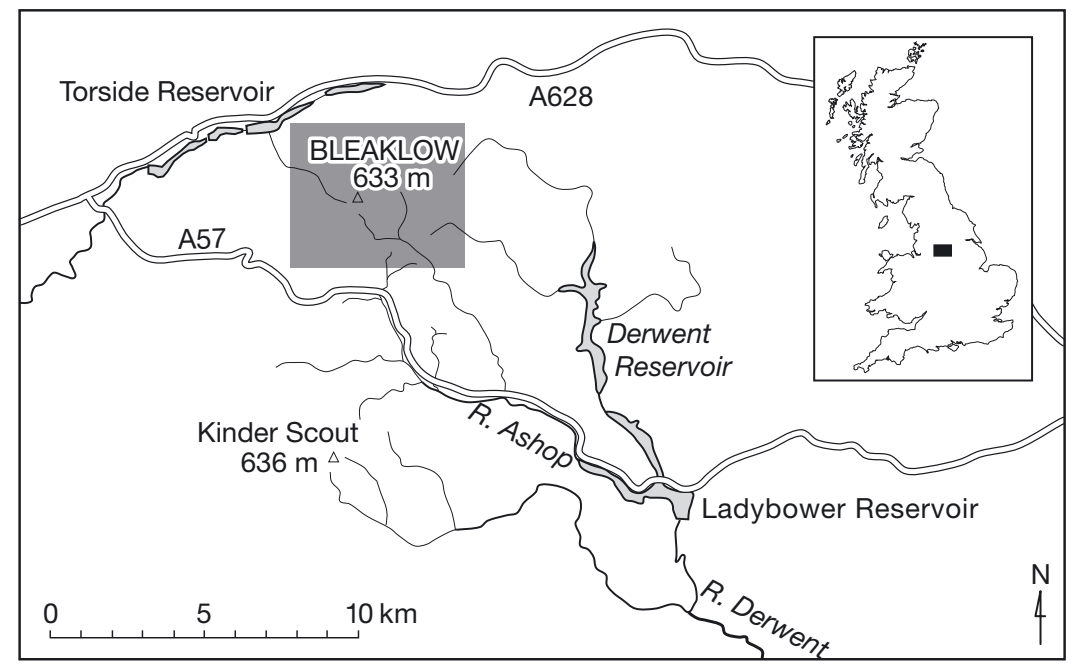

Fig. 2. The Bleaklow Plateau. The study area for gully mapping is shaded grey. A628 and A57 are roads 
blanket peatlands in the UK including wildfire, overgrazing, industrial pollution and climate change, and there is evidence for all these impacts in the southern Pennines (Tallis 1997). What is most remarkable about the Bleaklow Plateau is the very limited natural revegetation of the eroded areas which has led to particularly severe ongoing erosion. The southern Pennines were especially heavily impacted by 19th-20th century industrial pollution (Rothwell et al. 2007), and it has been suggested that suppression of revegetation by acid deposition plays a key role in the extent of bare peat at these sites (Evans \& Warburton 2007). Although the Bleaklow Plateau may represent a worst case scenario in terms of contemporary peat erosion, severe historic degradation is widespread across the UK, so the results from the present study are relevant to much of upland Britain, and potentially more widely if climate change drives more widespread peatland degradation.

\section{APPROACH}

Theoretically, 3 main impacts of gully erosion on the carbon balance of peatlands may be identified: (1) particulate organic carbon (POC) loss; (2) increased peat decomposition rates associated with water table drawdown in gully margin sites-more rapid decomposition will lead to gaseous loss of carbon as $\mathrm{CO}_{2}$ and also potentially to increased losses of DOC; and (3) carbon loss from gully systems due to vegetation loss and consequent changes in net ecosystem exchange (NEE) from the gullied areas.

In the present study we attempted to estimate the total carbon balance impact of gully erosion across the Bleaklow Plateau and to partition the carbon impact between these 3 principal impacts. The starting point for the landscape scale analysis is high resolution mapping of the gully networks on Bleaklow.

\subsection{Mapping gully systems across the Bleaklow Plateau}

In order to assess the impact of gully erosion on the peatland carbon balance of the Bleaklow Plateau, accurate mapping of the extent of gully erosion is required. A high resolution LiDAR digital elevation model (DEM) of the area is available. The data are a composite of data acquired in December 2002 and May 2005. Ground resolution is $2 \mathrm{~m}$ and the stated vertical accuracy is $0.25 \mathrm{~m}$. Maps of gully volume were derived from the DEM through application of an algorithm developed by Evans \& Lindsay (2010). The algorithm identifies gullies from DEM data on the basis that they are local low points in the landscape and areas of high plan curvature. Gully volumes are then derived by electronically 'filling in the gullies' through an interpolation routine and calculation of the fill volume. The basic steps of the method are:

(1) derivation of a Difference from Mean Elevation (DFME) image calculated as the difference from mean elevation in a $30 \mathrm{~m}$ circular window;

(2) production of a gully map based on thresholding of the normalised DFME image at a value of -0.25 and removal of noise by adding the requirement that gullies are areas of high positive plan curvature;

(3) linear interpolation of the DEM between gully edges defined from the gully map to create a 'preerosion' surface; and

(4) subtraction of the contemporary surface from the pre-erosion surface to create a gully depth map.

More detailed methodology and testing of the gully modelling is reported in Evans \& Lindsay (2010). The model validation indicates that gully depth and width are estimated to within the vertical and horizontal resolution of the imagery ( 2 and $0.25 \mathrm{~m}$ ) for all but the smallest gullies. Fig. 3a is a gully map of the Bleaklow Plateau produced according to these methods, which illustrates the extensive nature of the erosion across the peatland surface. Fig. 3b is a gully depth map of a small subcatchment on the southern edge of the plateau, which illustrates the detail derived from the gully depth mapping.

\subsection{Rates of carbon sequestration in intact and gully margin peat on Bleaklow}

The best available data on rates of carbon sequestration on Bleaklow comes from data on peat growth rates reported in Tallis (1994) and Tallis \& Livett (1994). Tallis (1994) described a series of cores from Alport Moor and Featherbed Moss, on the southern slopes of the Bleaklow Plateau. He identified 5 horizons, spanning the last $2500 \mathrm{yr}$, which, on the basis of pollen stratigraphy, could be correlated between cores. These horizons were dated using an age-depth profile derived from 19 radiocarbon dates from across the site. Peat growth rate data are presented for 4 time periods from 8 peat cores including 4 sites affected by gully erosion and 4 sites representing more intact peat. Overall peat growth rates are calculated for 28 separate periods. Of these, Tallis (1994) identifies 7 values as post-incision growth rates in cores immediately adjacent to erosion gullies. A further 4 (from Tallis' core FE1) are from a site potentially affected by peat margin drainage and the remainder of the rates are from intact sites or from the pre-erosion period at eroded sites. Table 1 summarises the available data. This peat growth data for intact sites represents aver- 

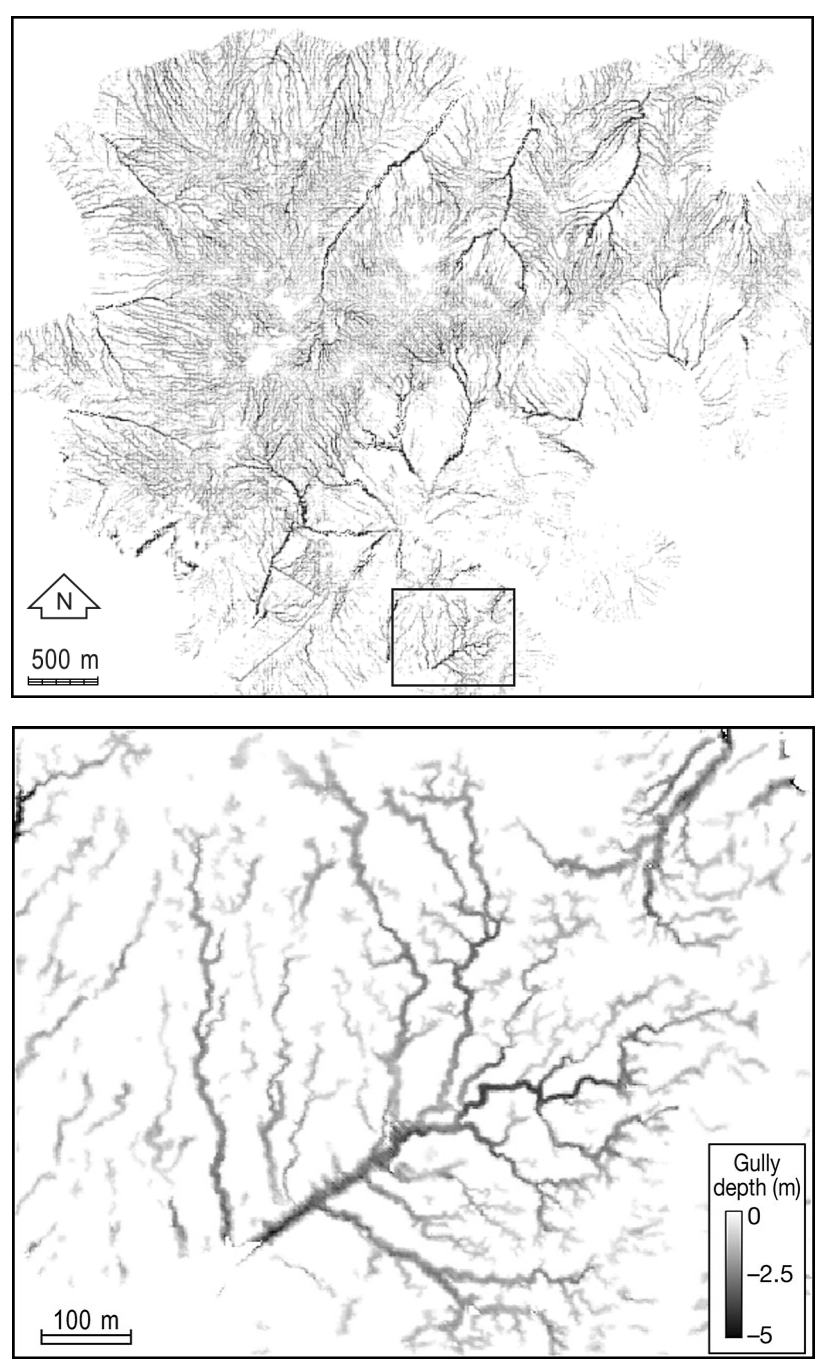

Fig. 3. (a) Gully map of the Bleaklow Plateau above $500 \mathrm{~m}$, showing gully depth (depth of gully floor below adjacent intact interfluve); the area of mapping is indicated in Fig. 2. (b) Detail of (a) showing the high resolution mapping achieved and the intricate and extensive nature of the gully erosion pattern across the plateau

age peat growth over the circa $3200 \mathrm{yr}$ period of the dating. The stated errors therefore include both spatial variation and temporal variation in peat growth rates over the time period. However, it is clear that the magnitude of the impact of gully inception on growth rates far exceeds the temporal variation at a site and spatial variation between sites. The post-erosion peat growth rates have a slight bias towards the later part of the time period since at 2 of the sites gullying post-dates $800 \mathrm{yr}$ BP and at a third it is post-1600 yr BP. However, the intact sites show no systematic trend of growth rates over time, so this factor is not considered to introduce systematic error. It is argued that the available data are a reasonable representation of the peat growth rates pre and post gully erosion averaged over the latter third of the Holocene.

The peat growth data may be re-interpreted as rates of carbon sequestration by estimating the carbon content of the peats. Pawson (2008) reports mean carbon content of $48 \%$ estimated for the organic fraction of suspended sediment in streams draining the Bleaklow Plateau. Such sediments can reasonably be expected to represent a well-mixed sample of peats from the system. This assumption is supported by measurements of bulk carbon content on nine $5 \mathrm{~cm}$ depth cores from the Bleaklow Plateau (Alport Moor) which yielded a mean percentage carbon content of $47.0 \pm 0.5 \%$. The present study has used $48 \%$ as a best estimate of landscape scale peat carbon content.

Applying this value to the measured peat growth rates gives average rates of net carbon sequestration of $7.9 \pm 2.5 \mathrm{~g} \mathrm{C} \mathrm{m}^{-2} \mathrm{yr}^{-1}$ in peats affected by gully erosion and $20.3 \pm 3.2 \mathrm{~g} \mathrm{C} \mathrm{m}^{-2} \mathrm{yr}^{-1}$ in uneroded areas. The confidence intervals in Table 1 and reported here for the carbon sequestration rates represent temporal and spatial variability in peat growth and/or carbon sequestration rates for the intact and eroded sites. They do not, however, take account of potential error in the core dating from which the growth rates are derived. Precise quantification of the dating error is problematic because it will include radiocarbon dating error, potential error in the core correlations and interpolation error from the application of the age-depth curve. Tallis' (1994) dating was based on the mean of the $1 \sigma$ range of the calibrated radiocarbon data. In order to take a conservative approach to potential error in the sequestration data, the $2 \sigma$ calibrated age range of the 19 radiocarbon dates reported in Tallis \& Livett (1994) was calculated. For dates in the last millennium the average relative error was $19 \%$, whereas for the period before $1000 \mathrm{yr}$ BP the average relative error was $9 \%$. This potential dating error has been regarded as an additional and independent source of error in the sequestration data. Since almost all the erosion post-

Table 1. Tabulation of peat growth rate data derived from Tallis (1994; see also for core identification). n: number of cores

\begin{tabular}{|lcccc|}
\hline Site character & $\mathrm{n}$ & $\begin{array}{c}\text { Mean growth rate } \\
\left(\mathrm{g} \text { [dry mass } \mathrm{m}^{-2} \mathrm{yr}^{-1}\right)\end{array}$ & $95 \%$ CI & Core identification \\
\hline Adjacent to gullies & 7 & 16.43 & 5.33 & SR1, SR3, $\mathrm{S}_{9}, \mathrm{~S}_{1}$ \\
Peat margins & 4 & 18.75 & 12.18 & FE1 \\
Intact & 17 & 42.25 & 6.72 & FT1, FW1, $\mathrm{S}_{6}, \mathrm{~S}_{9}, \mathrm{~S}_{1}, \mathrm{SR3}$ \\
\hline
\end{tabular}


dates $1000 \mathrm{yr} \mathrm{BP}$, the additional error is assumed to be $19 \%$ for eroded sites. For intact sites the overall average relative dating error of $12 \%$ is assumed to be reasonable. Combining these error estimates additively (as the root of the summed squared errors) with the estimates of spatial and temporal variability gives best estimates of the carbon sequestration rates of $7.9 \pm$ $3.0 \mathrm{gC} \mathrm{m}^{-2} \mathrm{yr}^{-1}$ (eroded sites) and $20.3 \pm 4.0 \mathrm{~g} \mathrm{C} \mathrm{m}^{-2}$ $\mathrm{yr}^{-1}$ (intact sites).

\subsection{Estimation of particulate carbon losses}

Rates of particulate carbon loss from the Bleaklow Plateau are known to be extremely high. Direct monitoring of streamflow POC concentrations has revealed that rates of loss range from 11 to $96 \mathrm{~g} \mathrm{C} \mathrm{m}^{-2} \mathrm{yr}^{-1}$ (Evans et al. 2006, Rothwell 2006, Evans \& Warburton 2007 , Pawson et al. 2008). Extrapolating these values to the wider landscape is not straightforward due to the spatial variability of erosion density revealed in Fig. 3a, and because these are contemporary data and it is known that rates of upland peat erosion have varied in the past in response to changing external forcing, in particular climate change and anthropogenic impacts on the peatland vegetation. An alternative approach is to estimate long-term erosion rates directly from the morphological evidence. Fig. 4 maps total volume of gully erosion across Bleaklow in 1 ha subcatchments (derived using the isobasin approach of Lindsay et al. 2006). The gully volume map can be converted to a POC loss map if 3 additional parameters are known: peat density, peat carbon content and the period of peat erosion. For the present study a peat density of $0.11 \mathrm{t}$ $\mathrm{m}^{-3}$ is assumed, derived from measurement of peat profiles on the Bleaklow Plateau (M. Evans unpubl. data). A carbon content of $48 \%$ was used as described above. The final requirement for estimation of POC flux from the erosion volume data is reliable dating of the phase of peat erosion. The Bleaklow Plateau has the best available dating of peat erosion onset based on the extensive work of Tallis $(1994,1995,1998)$ in developing a chronology of the onset of gully erosion in the area. Review of these works indicates that peat erosion was initiated over a period of time between about 1250 and 1750 AD. Based on Tallis (1994), the present study assumed a date for the onset of erosion of $500 \mathrm{yr}$ BP. The onset of erosion would not have been concurrent across the landscape however, and Tallis (1994) also dates earlier and later onset at some gullies. Based on this range, an error estimate of $\pm 250 \mathrm{yr}$ BP was applied to the assumed date in order to put conservative error bars around the estimate of landscape-wide, long-term average POC fluxes. This average flux value $\left(F_{\mathrm{POC}}\right)$ was calculated from the gully mapping based on the stated assumptions using the following equation:
Fig. 4. Total volume of gully erosion on Bleaklow Plateau mapped in 1 ha sub-catchments

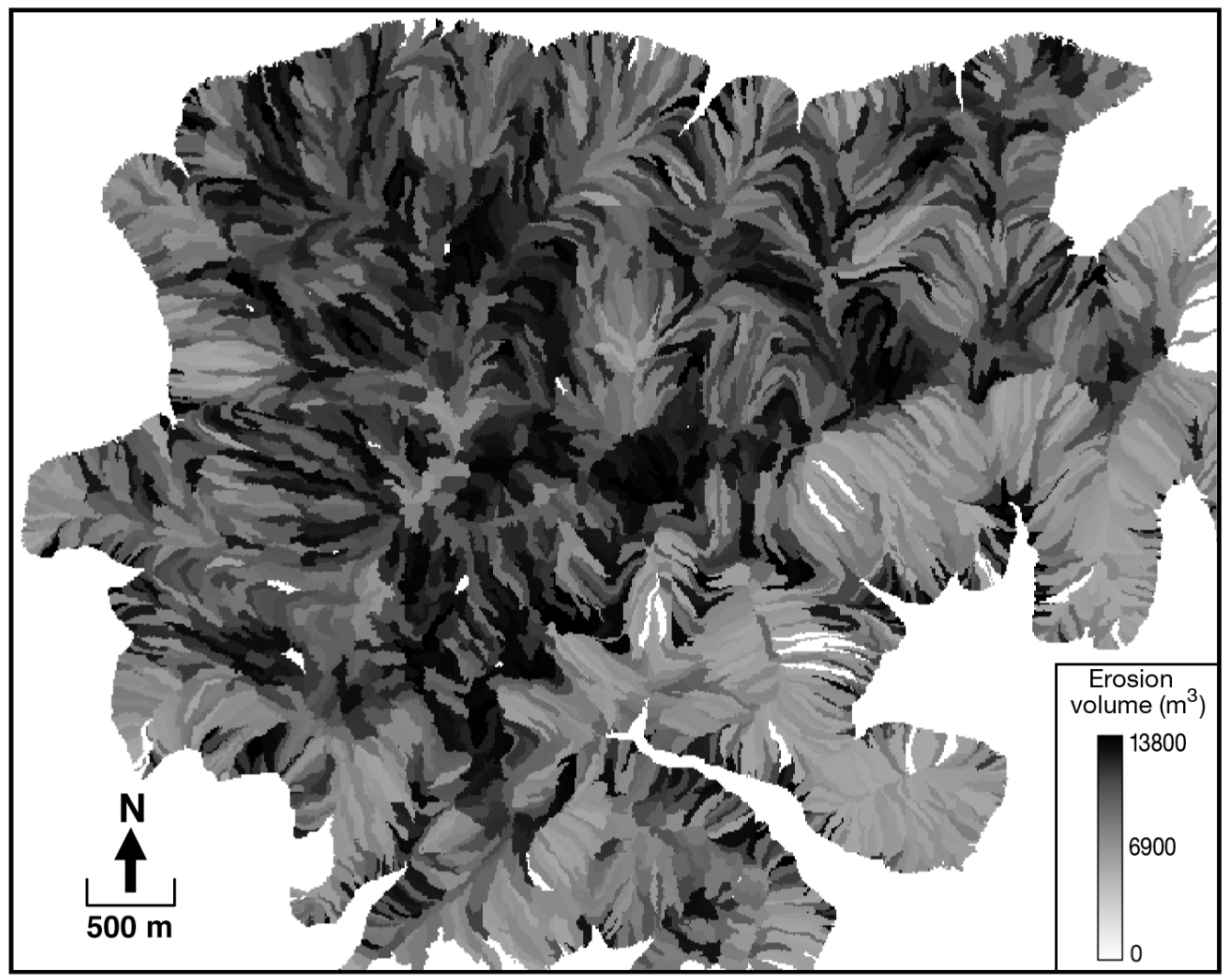




$$
F_{\mathrm{POC}}=V D C / T
$$

where $V$ is gully volume $\left(\mathrm{m}^{3}\right), D$ is peat density $\left(\mathrm{t} \mathrm{m}^{-3}\right)$, $C$ is peat carbon content (\%) and $T$ is the period time of peat erosion (yr).

Because the estimate of the period of erosion is not spatially distributed, a POC flux map would therefore not allow for spatial variation in onset of peat erosion, and the erosion rates are averaged over the whole period of erosion and do not allow for variation in rates. The latter is reasonable given the dating constraints on the erosion period; the former, however, means that POC flux estimates are better represented as a distribution which is assumed to be a reasonable estimate of long-term landscape averaged rates of peat erosion. The distribution of POC flux values by 1 ha subcatchments is plotted in Fig. 5 and yields an average POC flux of $30.9 \pm 1.0 \mathrm{gC} \mathrm{m}^{-2} \mathrm{yr}^{-1}$.

\subsection{The impact of gully erosion on NEE in gullied areas}

Gully erosion exposes large areas of bare peat comprising the walls and floors of the gully system. In larger gullies which have eroded to the mineral substrate beneath the peat there is also exposure of bare mineral ground. The simplest approach to modelling this effect across the landscape is to assume that the gully system is carbon neutral with close to zero soil respiration and primary productivity. The assumption of zero primary productivity in an unvegetated system is reasonable; however, there is uncertainty as to how to treat soil respiration and oxidation of bare peat. Potentially the losses by this mechanism are large. Waddington \& McNeil (2002) estimated oxidation losses from abandoned milled peatlands of $6 \mathrm{~mm} \mathrm{yr}^{-1}$. Similarly, Evans et al. (2006) estimated that average

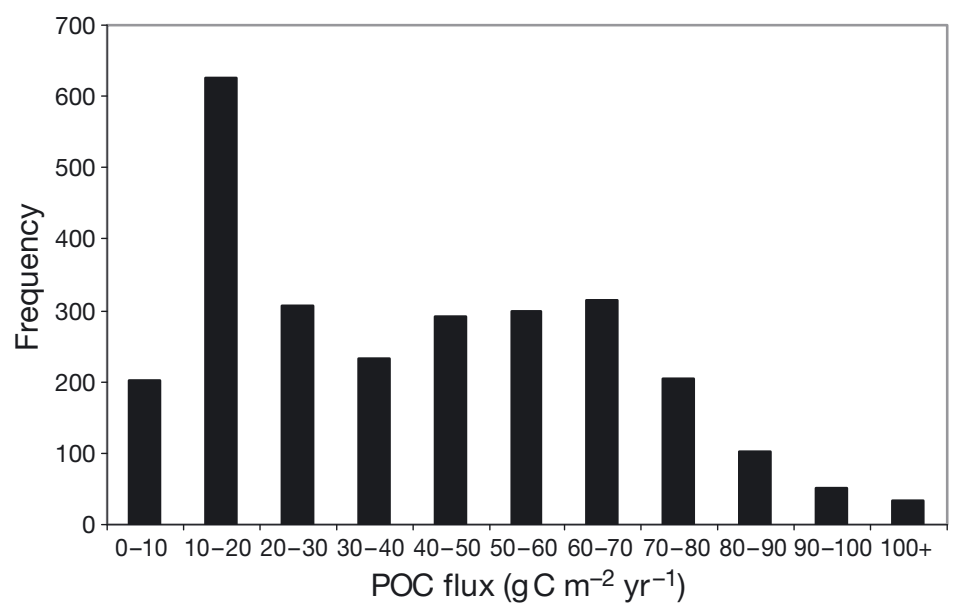

Fig. 5. Distribution of particulate organic carbon (POC) flux estimates derived from mapped 1 ha catchments on Bleaklow Plateau oxidation losses reported from eroding peatlands were 30 to $81 \%$ of observed surface recession. Even the lowest of these values applied to average surface recession rates from the Bleaklow Plateau indicates ca. $8 \mathrm{~mm} \mathrm{yr}^{-1}$ of oxidation recession. Converted to carbon loss, these figures equate to $>400 \mathrm{~g} \mathrm{C} \mathrm{m}^{-2} \mathrm{yr}^{-1}$. Direct measurements of carbon flux from bare peat reported in the literature indicate lower values in the range of 129 to $308 \mathrm{~g} \mathrm{C} \mathrm{m}^{-2} \mathrm{yr}^{-1}$ (Table 2). For one site on Bleaklow there are direct measurements of net ecosystem respiration from bare gully walls (monthly measurements of 3 chambers) which give a loss of $56 \mathrm{gC} \mathrm{m}^{-2} \mathrm{yr}^{-1}$ (F. Worrall unpubl. data). This value is taken as a best estimate for the site with an assumed range of 0 to $172 \mathrm{~g} \mathrm{C} \mathrm{m}^{-2} \mathrm{yr}^{-1}$, this latter figure being the average of the published data.

There is some minor potential for double counting of the oxidation flux, since $\mathrm{CO}_{2}$ flux from bare peats may in part result from the enhanced decomposition which reduces gully edge peat growth rates. However, the order of magnitude difference between the reduction in drainage rates and the apparent surface oxidation rates suggests that the oxidation is a surface process and not distributed through the gully margin peat mass.

\subsection{Estimation of landscape scale carbon budgets}

The gully mapping also provides a basis for extrapolating the carbon sequestration data to the scale of the whole plateau. Of the $22.8 \mathrm{~km}^{2}$ of blanket peat above $500 \mathrm{~m}$ elevation which is mapped in Fig. 2,7.9 km² or $35 \%$ of the area is gullied. Of the remainder, $3.45 \mathrm{~km}^{2}$ is in gully margin locations and has been sequestering carbon at a lower rate over the period of gully erosion. Average gully depth derived from the gully depth mapping is $2.06 \mathrm{~m}$ and the total length of gully wall in the study area is $1723 \mathrm{~km}$.

Table 3 presents estimated carbon budgets for the Bleaklow Plateau under a number of different scenarios. The carbon budgets were derived from the carbon sequestration and gully mapping data as follows.

\subsubsection{Net carbon sequestration in intact areas}

Net carbon sequestration in intact areas was calculated as the product of the intact carbon sequestration rate derived above from Tallis (1994) (20.3 $\left.\pm 4.0 \mathrm{gC} \mathrm{m}^{-2} \mathrm{yr}^{-1}\right)$ and the mapped area of intact peat. For the preerosion scenario this is assumed to be the whole plateau. 
Table 2. Estimated rates of $\mathrm{CO}_{2}$ flux from bare peat surfaces derived from literature sources

\begin{tabular}{|c|c|c|}
\hline & $\begin{array}{l}\text { Bare peat } \mathrm{CO}_{2} \text { flux } \\
\left(\mathrm{gC} \mathrm{m}^{-2} \mathrm{yr}^{-1}\right)\end{array}$ & Source \\
\hline Harvested bog surface & Min. 160 & Glatzel et al. $(2003)^{a}$ \\
\hline Restored cut away peatlands & Min. $80-250$ & Tuittila et al. (1999) ${ }^{a}$ \\
\hline Bare peat, maritime peatland & $163-308$ & Wilson et al. (2007) \\
\hline Tundra bare peat & 129 & Heikkinen et al. $(2004)^{\mathrm{b}}$ \\
\hline Gully walls on Bleaklow & 56 & F. Worrall pers. comm. \\
\hline \multicolumn{3}{|c|}{${ }^{\mathrm{a}}$ Seasonal flux; ${ }^{\mathrm{b}}$ extrapolated from $14.8 \mathrm{mg} \mathrm{m}^{-2} \mathrm{~h}^{-1}$} \\
\hline
\end{tabular}

\subsubsection{POC loss}

POC loss to the plateau is calculated as the product of plateau area $(22.8$ $\mathrm{km}^{2}$ ) and the average long-term POC loss derived from the gully mapping $\left(30.9 \pm 3.2 \mathrm{~g} \mathrm{C} \mathrm{m}^{-2} \mathrm{yr}^{-1}\right)$. It should be noted that small POC fluxes might be expected from intact peatlands. These are derived from diffuse surface erosion and are therefore effectively accounted for in the core-based peat

3.5.2. Net carbon sequestration in gully marginal areas

Lower carbon sequestration in gully marginal areas is assumed to be controlled by lower water tables which enhance rates of litter decomposition. Reduced carbon sequestration at sites with a lower water table reflects loss of carbon in both gaseous and dissolved forms. Previous work on water table drawdown in peatlands suggests that because the hydraulic conductivity of the peat is typically very low, the zone of influence of gullies or peatland drains is very short (Burke 1961, Stewart \& Lance 1991). Recent monitoring of gully edge water tables on Bleaklow has suggested that the average zone of influence of gullies in terms of immediate gully edge drawdown of the water table is only $2 \mathrm{~m}$ (Allott et al. 2009). Given that the resolution of the digital elevation data used in the present study is $2 \mathrm{~m}$, this amounts to a 1 pixel buffer around the gully map. The area of this zone within which carbon sequestration is reduced is calculated as $3.45 \mathrm{~km}^{2}$. Net carbon sequestration is calculated as the product of this area and the gully marginal carbon sequestration rate derived from Tallis (1994) $\left(7.9 \pm 3.0 \mathrm{~g} \mathrm{C} \mathrm{m}^{-2} \mathrm{yr}^{-1}\right)$. The difference between carbon sequestration calculated for the intact and gully marginal areas represents enhanced loss of gaseous and dissolved carbon due to erosion induced water table drawdown. accumulation rates. The POC loss associated with gully erosion is therefore the excess POC loss over the 'natural' rate.

\subsubsection{Gully area $\mathrm{CO}_{2}$ flux}

Two alternative assumptions are adopted for gully area $\mathrm{CO}_{2}$ flux. For Model 1, the gully systems are assumed to be carbon neutral. Primary productivity is reduced to zero and soil respiration rates are also zero. An alternative assumption is also modelled using the bare peat respiration data reported in Table 2 as a reasonable flux from gully walls. A range of 0 to $172 \mathrm{~g} \mathrm{C}$ $\mathrm{m}^{-2} \mathrm{yr}^{-1}$ with a best estimate of $56 \mathrm{gC} \mathrm{m}^{-2} \mathrm{yr}^{-1}$ was combined with the area of gully walls across the plateau derived from the gully mapping $(1723 \mathrm{~km}$ of gully walls with average depth $2.06 \mathrm{~m}$ ) to estimate total respiration flux from bare gully walls.

\subsubsection{Treatment of error}

Potential error in the carbon sequestration data is estimated as the $95 \% \mathrm{CI}$ of the mean as described above. POC flux error is a function of the $\pm 250 \mathrm{yr}$ error bar on the estimated age of onset of erosion. This creates an asymmetric error range around the estimated

Table 3. Estimated carbon budget for the Bleaklow Plateau under 3 scenarios: (1) a pre-erosion scenario; (2) Model 1, an estimate of post-erosion carbon budget including the calculated particulate organic carbon (POC) loss and assuming that the gully walls are not a carbon source; and (3) Model 2, an estimate of the post-erosion carbon budget including POC loss and an estimate of $\mathrm{CO}_{2}$ losses from bare gully walls. Data are best estimates, as detailed in Section 3.5 (parentheses: error estimates, as detailed in Section 3.5.5)

\begin{tabular}{|c|c|c|c|c|c|}
\hline Scenario & $\begin{array}{l}\text { Carbon sequestration } \\
\text { by intact peat }(\mathrm{t})\end{array}$ & $\begin{array}{l}\text { Carbon sequestration } \\
\text { in gully marginal } \\
\text { locations }(\mathrm{t})\end{array}$ & $\begin{array}{l}\text { POC } \\
\text { loss } \\
(\mathrm{t})\end{array}$ & $\begin{array}{l}\text { Gully area } \\
\mathrm{CO}_{2} \text { flux } \\
\text { (t) }\end{array}$ & $\begin{array}{l}\text { Net carbon } \\
\text { sequestration } \\
\left(\mathrm{gC} \mathrm{m}^{-2} \mathrm{yr}^{-1}\right)\end{array}$ \\
\hline Pre-erosion & $\begin{array}{c}-463.0 \\
(-390 \text { to }-546)\end{array}$ & 0 & 0 & 0 & $\begin{array}{c}-20.3 \\
(-23.5 \text { to }-17.1)\end{array}$ \\
\hline Model 1 & $\begin{array}{c}-233.7 \\
(-196.8 \text { to }-270.6)\end{array}$ & $\begin{array}{c}-27.3 \\
(-18.3 \text { to }-36.3)\end{array}$ & $\begin{array}{c}704.8 \\
(469.9 \text { to } 1409.7)\end{array}$ & 0 & $\begin{array}{c}19.5 \\
(-2.8 \text { to } 82.9)\end{array}$ \\
\hline Model 2 & $\begin{array}{c}-233.7 \\
(-196.8 \text { to }-270.6)\end{array}$ & $\begin{array}{c}-27.3 \\
(-18.3 \text { to }-36.3)\end{array}$ & $\begin{array}{c}704.8 \\
(469.9 \text { to } 1409.7)\end{array}$ & $\begin{array}{c}198.8 \\
(0 \text { to } 610.7)\end{array}$ & $\begin{array}{c}29.4 \\
(6.7 \text { to } 120)\end{array}$ \\
\hline
\end{tabular}


annual POC flux. Similarly, the error estimates for the gully wall oxidation estimates are reasonable maximum and minimum figures derived from the literature and are also asymmetric around the best estimate value. In order to combine these errors to provide overall error estimates for the carbon budget, the symmetrical error terms were combined as the root of the summed square of the errors, but the asymmetric errors were calculated as additive maximum and minimum error terms for the budget. The error terms on the final budget numbers are therefore conservative since no account has been made for offsetting error in 2 of the larger terms in the budget. The carbon budget estimates with associated error ranges are presented in Table 3.

\section{DISCUSSION}

\subsection{Bleaklow carbon budgets}

The data presented in Table 3 represent estimates of the long-term average effect of the erosion of upland peat on the peatland carbon budget. The baseline is a pre-erosion carbon balance of $-20.3 \mathrm{gC} \mathrm{m}^{-2} \mathrm{yr}^{-1}$ which derives directly from the Tallis (1994) sequestration data. This value is reasonable in the context of reported carbon sequestration values for northern peatlands (Gorham 1991), but is at the lower range of values reported by Worrall et al. $(2003,2009)$ for blanket peatlands in the northern Pennines, and is at the lower end of measured UK values reported in Billett et al. (2010, this Special). This is consistent with the southerly position and relative dryness of the southern Pennines; however, it should be noted that the values are also lower than measured data at an intact Bleaklow site (Billett et al. this Special). Peatland carbon balance typically shows strong interannual variability so it is unsurprising that the long-term data do not exactly replicate short-term measurements, but in the context of the wider data the baseline estimates are not unreasonable.

The gully mapping has allowed estimates to be made for carbon losses associated with gully erosion. Two further models have been calculated based on differing assumptions. Model 1 estimates POC loss from the gully mapping and reductions in gully marginal carbon sequestration are estimated by using the gully map to extrapolate the data derived from Tallis (1994). Direct primary productivity loss associated with vegetation loss in gullies is estimated based on the assumption that unvegetated gully floors and walls neither fix nor release carbon. Under these conditions the extremely high POC losses associated with the severe long-term erosion occurring on the Bleaklow Plateau dominate the carbon balance. The onset of erosion produces a shift from a carbon sink of $-20.3 \mathrm{~g} \mathrm{C} \mathrm{m}^{-2} \mathrm{yr}^{-1}$ to a carbon source of $+19.5 \mathrm{~g} \mathrm{C} \mathrm{m}^{-2} \mathrm{yr}^{-1}$. Of this shift, POC loss accounts for $78 \%$ of the loss whilst reductions in gully marginal sequestration account for just $5 \%$ of the loss. The balance $(17 \%)$ is due to the loss of primary productivity in gullied areas (Fig. 6a).

Model 2 modifies Model 1 by accounting for $\mathrm{CO}_{2}$ loss from the bare peat walls exposed by gully erosion in addition to the loss of primary productivity in gullies. The impact of this additional assumption is to shift the carbon balance from a sink of $-20.3 \mathrm{~g} \mathrm{C} \mathrm{m}^{-2} \mathrm{yr}^{-1}$ to a source of $+29.4 \mathrm{gC} \mathrm{m}^{-2} \mathrm{yr}^{-1}$. In these conditions the largest effect of the gully erosion is still POC loss at $63 \%$ of the loss. Loss of productivity and oxidation of gully walls account for $32 \%$ of the loss of sequestration capacity, whilst reduced gully marginal peat growth is only $4 \%$ of the loss (Fig. 6b).

The models both demonstrate the very significant impact of gully erosion on the carbon sequestration capacity of the peatland. Even the more conservative Model 1 indicates that gully erosion on Bleaklow shifts the peatland from a net carbon sink to a source of similar magnitude, whilst Model 2 indicates very significant carbon losses associated with POC loss and the exposure of bare peat. The large magnitude of the POC flux and the potential loss by oxidation of bare peat highlight 2 important areas which require further research, namely the fate of the POC flux and gas flux from bare peat areas.

\subsection{Comparison with monitored data}

The carbon balance data presented in Table 3 show smaller variability, and smaller overall magnitudes than the monitored carbon balances for Bleaklow reported in Billett et al. (this Special). This is to be expected as the long term estimates over the whole plateau include very significant spatial and temporal

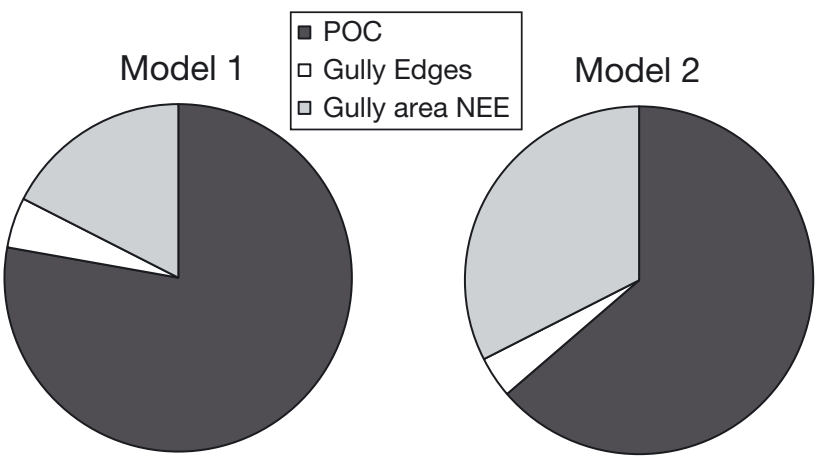

Fig. 6. Proportion of total carbon loss due to particulate organic carbon (POC) flux, net ecosystem exchange (NEE) change and reduced gully marginal sequestration for Models 1 and 2 
averaging of variability. What however is consistent between the monitored data and the data presented here is the potential for modification of the peatland system, in this instance gully erosion, to shift the whole landscape from a long term carbon sink to a significant carbon source.

\subsection{Limitations of the approach}

The compilation of data and modelling presented here has allowed for the first time an attempt to disaggregate the effects of gully erosion on peatland carbon balance at the landscape scale. Nevertheless, there are limitations to the approach which must be acknowledged. Firstly, there is no direct account taken of methane fluxes within the carbon balance estimates presented. For the intact peats the methane flux is part of the net sequestration value and so is included in the budget; however; recent work has demonstrated that revegetating gullies can result in hotspots of methane production (McNamara et al. 2008). Where gully revegetation occurs this may be a further component of the carbon balance which is impacted by gully erosion. Similarly, no direct account is taken of gully revegetation. Recent work has demonstrated that natural gully revegetation is occurring on the Bleaklow Plateau (Crowe et al. 2008), and the carbon balance of revegetating gully floors is an area which requires further work. In the present study the assumption is made that the gully floors are bare; therefore, the results indicate the impact of onset of erosion but not the effects of revegetation.

A further limitation of the present study is the assumption that the existing gullied landscape represents a single phase of erosion dated to $500 \mathrm{yr}$ BP. The large error bars assumed around this date mean that at the landscape scale the range of POC fluxes is reasonable; however, there is some indication that there may be multiple phases of erosion. Fig. 4 is bi-modal and may indicate 2 phases of erosion consistent with the suggestion of Tallis (1994) that there was further erosion initiated during the Little Ice Age (ca. 1750 AD). For this reason POC flux estimates for smaller gullies may be underestimates so that the mean overall rate of POC loss estimated for the landscape may be conservative. Finally, the impact of reduced water tables is only modelled for the immediate gully marginal areas where direct drawdown of the water table is observed. Recent work has suggested that there may be a second, more diffuse impact of gullying on the water table through reduced upslope water supply (Allott et al. 2009). A similar effect has been observed for drained systems (Holden et al. 2006). This would have the effect of reducing carbon sequestration across a wider area of the landscape and further increase the impact of gullying on the carbon balance. It should, however, be noted that the secondary water table drawdown effect in gullied areas is approximately an order of magnitude lower than the gully marginal impact (Allott et al. 2009). In summary, the present study modelled 3 main impacts of gully erosion on the carbon balance, but is not a complete description of the impacts. The approach is intentionally conservative and arguably produces a minimum estimate of the impact of gully erosion whilst describing the relative importance of 3 major effects.

\subsection{Greenhouse gas impacts of the carbon budget}

The aim of the present study was to consider the impact of gully erosion on the peatland carbon budget. Nevertheless, it is useful to consider the potential implications of the observed changes in the carbon budget for the greenhouse gas (GHG) budget of the system. The largest unknown with respect to the impact of the POC flux on peatland GHG budgets is the fate of particulate carbon. If POC is transported to burial sites in the reservoirs or the ocean and buried, then it represents a net loss of carbon to the peatland but not a flux to the atmosphere. Recent work has indicated that eroded peat is not transported as an inert flux but is subject to transformation to DOC in the river system, and oxidation in sediment storage zones within the river system such as floodplain surfaces (Pawson 2008). The magnitude of such losses is poorly understood, but initial work suggests that $30 \%$ might represent a conservative estimate (Pawson 2008).

Reduced gully marginal carbon sequestration is assumed to be due to enhanced litter decomposition. These losses will be partitioned between direct loss of $\mathrm{CO}_{2}$ to the atmosphere and flushing of DOC from the upper layers of the peat. DOC can be a significant component of total carbon loss from peatland systems (Dinsmore et al. 2010). On the Bleaklow Plateau, Pawson (2008) reported measured DOC losses equivalent to $38 \%$ of NEE. However, as Worrall et al. (2009) has demonstrated that DOC is rapidly decomposed in peatland headwaters, it is likely that the majority of the carbon loss due to litter decomposition can be regarded as climatically active.

The third control of gullying on the carbon budget considered here is the impact of bare peat oxidation and changes in primary productivity within the gullies. These are direct impacts on gaseous carbon flux and therefore translate directly into impacts on the GHG budget. If $30 \%$ is adopted as a figure of merit for the proportion of the POC flux which is converted to GHG, and the other components of Model 2 are assumed to 
be climatically active, then the ordering of the erosion impacts changes to: change in gully NEE > POC loss $>$ reduction in gully marginal carbon sequestration, but the system remains a net carbon source of $6.5 \mathrm{~g} \mathrm{C} \mathrm{m}^{-2}$ $\mathrm{yr}^{-1}$. These calculations exclude any effect of gullying on $\mathrm{CH}_{4}$ or $\mathrm{NO}_{2}$ fluxes but they highlight the potential importance of gully erosion-induced changes in peatland carbon balance for overall peatland GHG exchange. These results also emphasise the urgent need for more complete monitored carbon and GHG flux data from eroding peatlands to fully quantify the impacts of erosion on contemporary carbon storage and/or release.

\subsection{Implications}

Despite the inevitable caveats associated with working at landscape scale, the results presented in the present study have clear implications for our understanding of the function of eroded peatlands and the potential to restore degraded systems to become carbon sinks. In a management context, restoration of vegetation to peatland surfaces has proved achievable (Anderson et al. 2009), but restoration of pre-erosion morphology is not an achievable short- or mediumterm aim. Natural revegetation of gully floors and managed restoration of vegetation cover through seeding have been demonstrated to significantly reduce POC flux from degraded systems (Evans \& Warburton 2005, Evans 2008). The enhanced POC flux associated with phases of gully erosion is therefore a potentially reversible impact on the peatland carbon balance. Restoration of the water table in peatlands affected by deep gullying is much more difficult. Although gully blocking has successfully been implemented to raise water tables and control sediment flux from relatively small headward gully systems, no effective methods have been developed to restore water tables in deep $(2 \mathrm{~m})$ gullies. The finding of the present study that reductions in gully marginal carbon sequestration are the smallest component of the carbon losses associated with gullying is therefore positive, since this component of the impact of gullying on the carbon balance is effectively irreversible. The magnitude of the lost primary productivity associated with gully erosion is significant (17\% in Model 1). This effect of gully erosion has not previously been widely noted, and the efficacy of gully revegetation suggests that the loss of primary productivity can be easily restored, although this does not necessarily entail a return to pre-erosion NEE levels because of the uncertain impacts of restoration on soil respiration. This is an area which requires further research in the context of gullied systems.

\section{CONCLUSIONS}

The present study has demonstrated that in the severely eroded peatlands of the Bleaklow Plateau in the English southern Pennines, the onset of erosion has transformed the peatland from a net carbon sink to, at best, a carbon neutral status and most likely a significant carbon source. The impact of gully erosion on the carbon balance has been quantified as 3 components: POC flux, change in gully NEE and reduced carbon sequestration due to gully marginal water table drawdown. It has been shown that in terms of the peatland carbon balance, POC loss is dominant so that POC flux $>$ change in NEE $\gg$ reduced gully margin sequestration. The findings suggest that despite the irreversible morphological changes associated with gully erosion, the carbon balance impacts may be largely reversible, but also emphasise the urgent need for more research to elucidate rates and mechanisms of POC transformation to climatically active forms, and the need to understand rates of soil respiration from bare peat surfaces. More field data on the full range of carbon fluxes from eroding peatlands are required for comparison with the long-term, landscape-scale estimates presented here.

Acknowledgements. The LiDAR data was made available by Moors for the Future with the permission of the National Trust. F. Worrall has kindly allowed us to cite unpublished soil respiration data from a site on Bleaklow. The authors also acknowledge the continuing support of the National Trust for research on Bleaklow and financial support from the Manchester Geographical Society. Excellent reviews from 3 anonymous referees significantly improved the final version of this paper.

\section{LITERATURE CITED}

Allott TEH, Evans MG, Lindsay JL, Agnew CT, Freer JE, Jones A, Parnell M (2009) Water tables in Peak District blanket peatlands. Report to Moors for the Future, Edale

Anderson P, Buckler M, Walker J (2009) Moorland restoration: potential and progress. In: Bonn A, Allott TEH, Hubackeck K, Stewart J (eds) Drivers of environmental change in uplands. Routledge, London

> Billett MF, Burden A, Charman DJ, Clark J and others (2010) Carbon balance of UK peatlands: current state of knowledge and future research challenges. Clim Res 45:13-29

- Blodau C, Basiliko N, Moore TR (2004) Carbon turnover in peatland mesocosms exposed to different water table levels. Biogeochemistry 67:331-351

Burke W (1961) Drainage investigations on bogland: the effects of drain spacing on ground water levels. Isr J Agric Res 1:31-34

Charman DJ (1992) Blanket mire formation at the Cross Lochs, Sutherland, northern Scotland. Boreas 21:53-72

Clark JM, Orr HG, Freer J, House J, Smith P, Freeman C (2010) Assessment of projected changes in upland environments using simple climatic indices. Clim Res 45:87-104

Crowe SK, Evans MG, Allott TEH (2008) Geomorphological controls on the re-vegetation of erosion gullies in blanket 
peat: implications for bog restoration. Mires Peat 3:1-14 Dinsmore KJ, Billett MF, Skiba UM, Rees RM, Drewer J, Helfter C (in press) Role of the aquatic pathway in the carbon and greenhouse gas budgets of a peatland catchment. Global Change Biol doi:10.1111/j.1365-2486.2009.02119.x

Evans M (2008) Monitoring carbon flux from moorland restoration sites on Bleaklow. Report to Moors for the Future and Natural England, Edale

Evans M, Lindsay J (2010) Quantifying gully erosion in upland peatlands at the landscape scale: gully mapping from a high resolution LiDAR DEM. Earth Surf Process Landf 35:876-886

Evans M, Warburton J (2005) Sediment budget for an eroding peat-moorland catchment in Northern England. Earth Surf Process Landf 30:557-577

Evans M, Warburton J (2007) The geomorphology of upland peat: pattern, process, form. Blackwell, Oxford

Evans M, Warburton J, Yang J (2006) Sediment budgets for eroding blanket peat catchments: global and local implications of upland organic sediment budgets. Geomorphology 79:45-57

Glatzel S, Kalbitz K, Dalva M, Moore T (2003) Dissolved organic matter properties and their relationship to carbon dioxide efflux from restored peat bogs. Geoderma 113: $397-411$

Gorham E (1991) Northern Peatlands: role in the carbon cycle and probable responses to climatic warming. Ecol Appl 1: 182-195

Heikkinen JEP, Virtanen T, Huttunen JT, Elsakov V, Martikainen PJ (2004) Carbon balance in East European tundra. Global Biogeochem Cycles 18:GB1023. doi:10.1029/ 2003GB002054

Holden J, Evans MG, Burt TP, Horton M (2006) Impact of land drainage on peatland hydrology. J Environ Qual 35: $1764-1778$

Lindsay R, Charman D, Everingham F, O'Reilly R, Palmer M, Rowell T, Stroud D (1988) The flow country: the peatlands of Caithness and Sutherland. NCC, Peterborough

Lindsay JB, Liddaman L, Evans M, McMorrow J (2006) Swapping subcatchments for isobasins. Proc GISRUK Nottingham, 5-7 April 2006. University of Nottingham, Nottingham

McNamara NP, Plant T, Oakley S, Ward S, Wood C, Ostle N (2008) Gully hotspot contribution to landscape methane $\left(\mathrm{CH}_{4}\right)$ and carbon dioxide $\left(\mathrm{CO}_{2}\right)$ fluxes in a northern peatland. Sci Total Environ 404:354-360

Milne R, Brown TA (1997) Carbon in the vegetation and soils of Great Britain. J Environ Manage 49:413-433

Pawson RR (2008) Assessing the role of particulates in the fluvial organic carbon flux from eroding peatland systems. $\mathrm{PhD}$ thesis, University of Manchester

Pawson RR, Lord DR, Evans MG, Allott TEH (2008) Fluvial organic carbon flux from an eroding peatland catchment, southern Pennines, UK. Hydrol Earth Syst Sci 12:625-634
Rodwell JS (1991) British plant communities, Vol 2: mires and heaths. Cambridge University Press, Cambridge

Rothwell JJ (2006) Fluvial export of heavy metals from contaminated and eroding peatlands, southern Pennines, UK. $\mathrm{PhD}$ thesis, University of Manchester

Rothwell JJ, Evans MG, Lindsay JB, Allott TEH (2007) Scaledependent spatial variability in peatland lead pollution in the southern Pennines, UK. Environ Pollut 145:111-120

Silvola J, Alm J, Ahlholm U, Nykanen H, Martikainen PJ (1996) CO2 fluxes from peat in Boreal mires under varying temperature and moisture conditions. J Ecol 84:219-228

> Stewart AJ, Lance AN (1991) Effects of moor-draining on the hydrology and vegetation of northern Pennine blanket bog. J Appl Ecol 28:1105-1117

Strack M, Waddington JM, Bourbonniere RA, Buckton EL, Shaw K, Whittington P, Price JS (2008) Effect of water table drawdown on peatland dissolved organic carbon export and dynamics. Hydrol Process 22:3373-3385

Tallis JH (1991) Forest and moorland in the south Pennine uplands in the mid-Flandrian period. III. The spread of moorland-local, regional and national. J Ecol 79:401-415

Tallis JH (1994) Pool-and-hummock patterning in a southern Pennine blanket mire. II. The formation and erosion of the pool system. J Ecol 82:789-803

Tallis JH (1995) Climate and erosion signals in British blanket peats: the significance of Racomitrium lanuginosum remains. J Ecol 83:1021-1030

Tallis JH (1997) The southern Pennine experience: an overview of blanket mire degradation. In: Tallis $\mathrm{JH}$, Meade R, Hulme PD (eds) Blanket mire degradation: causes, consequences and challenges. Macaulay Land Use Research Institute, Aberdeen, p 7-16

Tallis JH (1998) Growth and degradation of British and Irish blanket mires. Environ Rev 6:81-122

Tallis JH, Livett EA (1994) Pool-and-hummock patterning in a southern Pennine blanket mire. I. Stratigraphic profiles for the last 2800 years. J Ecol 82:775-788

> Tuittila ES, Komulainen VM, Vasander H, Laine J (1999) Restored cut-away peatland as a sink for atmospheric $\mathrm{CO}_{2}$. Oecologia 120:563-574

> Waddington JM, Griffis TJ, Rouse WR (1998) Northern Canadian wetlands: net ecosystem $\mathrm{CO}_{2}$ exchange and climate change. Clim Change 40:267-275

Waddington JM, McNeil P (2002) Peat oxidation in an abandoned cutover peatland. Can J Soil Sci 82:279-286

> Wilson D, Tuittila ES, Jukka ALM, Laine J, Farrell EP, Byrne KA (2007) Carbon dioxide dynamics of a restored maritime peatland. Ecoscience 14:71-80

Worrall F, Reed M, Warburton J, Burt TP (2003) Carbon budget for British upland peat catchment. Sci Total Environ 312:133-146

Worrall F, Burt TP, Rowson JG, Warburton J, Adamson JK (2009) The multi-annual carbon budget of a peat-covered catchment. Sci Total Environ 407:4084-4094

Proofs received from author(s): August 17, 2010 